\title{
THE IMPACT OF COMPETITIVE ADVANTAGE OF HOtEL ProductS ON ATtRaCting CUSTOMERS
}

\author{
By \\ Ghada Atef Elshabrawy \\ Research Master Thesis \\ Faculty of Tourism and Hotels - \\ Mansoura University \\ Mohamed Abd El Fattah Zohry \\ Talaat Asaad Abdel-Hamid \\ Lecturer of Hotel management- \\ Prof. of Business Administration - \\ Faculty of Tourism and Hotels - \\ Faculty of Commerce - \\ Mansoura University \\ Mansoura University

\section{Research Journal of the Faculty of Tourism and Hotels Mansoura University}

ISSUE NO. 2, DECEMBER. 2017

مجلة كلية السياحة والفنادق - جامعة المنصورة

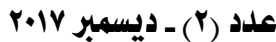




\title{
The Impact of Competitive Advantage of Hotel Products on ATTRACTING CUSTOMERS
}

\author{
Ghada Atef \\ Elshabrawy ${ }^{1}$
}

\author{
Mohamed Abd El Fattah \\ Zohry ${ }^{2}$
}

Talaat Asaad
Abdel-Hamid $^{3}$

\begin{abstract}
Many studies indicate that the value of the company products is achieving by obtaining a competitive advantage of its products over its competitors, as a competitive advantage is important for any organization to survive in the fierce competition. This research was conducted with the purpose of determine the impact of hotel products competitive advantage (presented in, hotel products differentiation, hotel products efficiency, hotel products quality, and hotel products innovation) on attracting customers. As the problem of this research is summarized in the absence of the thorough understanding of the real meaning of the concept of product competitive advantage in Egyptian hotels, as well as the high cost of the hotel product competitive advantage creation, in addition the absence of the effective management of the hotel available resources and capabilities. For this propose an empirical study has been conducted on a sample of five-star hotel customers at Sharm El Shiekh City, to investigate the significant of the hotel product competitive advantage effect on attracting customers. Study findings reveal that there is significant effect of hotel product competitive advantage on attracting customers in the terms of hotel products differentiation, hotel products efficiency, and hotel products quality. Nevertheless, the study raises a number of recommendations which depend on give more interest to hotel products innovation items, as well as paying attention of keeping up with technology
\end{abstract}

Keywords: Competitive advantage, Quality, Efficiency, Innovation, Differentiation, Products. 
العديد من الدراسـات أوضحت أن قيمـة منتججات الشركة تنبع مـن امتالاك المنشأة ميزة تنافسية عن منافسيها، حيث أن اى منشأة تحتاج الى ميزة تنافسية من أجل البقاء ومواجهة حدة المنافسلة. وقد أجريت هذه الدراسـة بهدف تحديد تأثير الميزة التنافسية للمنتجات الفندقية ( متمثلة فى: تميز المنتجات الفندقية، كفاءة المنتجات الفندقية، جودة المنتجات الفندقية، وتطوير المنتجات الفندقية) على جذب العملاء. تتلخص مشكلة الدراسـة فى غياب الفهم الكامل لمفهوم الميزة التنافسية للمنتجات فى الفنادق المصرية، والتكلفة المرتفعة اللازمة لخلق ميزة تنافسية للمنتجات الفندقية، وكذلك غياب دور الإدارة الفعالة للموارد والقدرات المتاحة لدى الفنادق. ولذلك تم عمل دراسة ميدانيـة على عينـة من عملاء الفنـادق فئلة الخمس نجوم فى مدينـة شرم الشيخ للتحقق من تأثير الميزة التنافسية للمنتجات الفندقية على جذب العملاء. وقد أوضحت النتائج وجود تأثير معنوى للميزة التنافسية للمنتجات الفندقية على جذب العملاء فيما يخص (تميز المنتجات الفندقية، جودة المنتجات الفندقية، كفاءة المنتجات الفندقية). و قد توصل البحث الى مـجموعة من التوصيات مـن أهمها اعطاء الفنادق اهتمام أكبر بالعناصر الخاصلة بالتطوير، وكذلك الاهتمام بهواكبة التكنولوجيا. 


\section{Introduction}

The hospitality industry is one of the most important major industries complementary to the tourism industry. The hospitality industry can be defined as the "Collection of business which provides individuals with accommodation, food, beverage and other services such as entertainment, recreation and so on" (Metwaly, 2014, pp.1,2*).

In the hotel industry competitive intensity increases due to an increased number of operating units, providing new products, and new market entries (Kim and Oh, 2004). Since, the hotel determines its competitors according to the price similarity, market segment, and proximity (Mathews, 2000), so hotel can decrease the degree of rivalry by differentiating its products and services (Enz, 2010, p.37).

Consequently, most of hotel organizations are interested in excellence for the purpose of survive and concentration in the market and to obtain the largest market share compared with other competitors. And as, potential customers are increasingly looking for the unique characteristics of hotel offers. So, in order to survive in the fierce international competition, hotel has to offer for whether its customers or potential customers an added value that they do not receive from other competitors, through achieving a competitive advantage over its competitors (Frehse, 2008).

So, achieving a competitive advantage is considered as the single most important goal of a hotel, because without achieving competitive advantage, hotel will have few economic reasons for existing and finally will get away (Kim and Oh, 2004).

\section{Research Problem}

The Research problem is summarized in:

- There are many resources of competitive advantage but it don't well exploited.

- The creating of a competitive advantage is costly and difficult to achieve.

\section{Research Hypothesis}

There is a significant effect of hotel products competitive advantage on attracting customers. Which is divided into four sub hypotheses as follows:

H1.There is a significant effect of hotel products differentiation on attracting customers. 
$\mathrm{H} 2$. There is a significant effect of hotel products efficiency on attracting customers.

H3.There is a significant effect of hotel products quality on attracting customers.

H4.There is a significant effect of hotel products innovation on attracting customers.

\section{Research Objectives}

This research aims to:

- Identify the concept of competitive advantage.

- Recognize how to build a product competitive advantage in Egyptian hotels.

- Investigate the impact of competitive advantage for hotel products on attracting customers.

\section{Research Importance}

The importance of this research stems from the institution need of competitive advantage in order to strengthen its competitive position. So, the hotel establishments must give the competitive advantage a special attention especially in terms of hotel products, because products are the basic of any industry in attracting customers. This research will help hotels to access to the means that able them to create competitive advantages and determine strength and weakness points, and then expand its market share. Especially in the light of current dimensions the Egyptian hotels and tourism industry suffered from and its need to a private innovative ability in building new product competitive advantages that attract customers.

\section{Literature review}

\section{Competitive advantage}

The notion of competitive advantage implies performing better than competitors or all other firms in the industry (Siqueira and Cosh, 2008). A company is said to have competitive advantage whenever it has an edge over rivals in securing customers and defending against competitive forces (Porter,1998a, p.6).

According to Albakri, (2010, pp.67-89*) Competitive advantage means; Organization's ability to attract customers and build prestige for the organization or its products and increase perceived value by customers and achieve their satisfaction, which is also the ability to provide variety value to the customer. 
ب مجلة كلية السياحة والفنادق - عدد - - ديسمبر

As porter, (1998b, p.11), stated that, a firm can possess two basic types of competitive advantage; low cost or/and differentiation.

\section{Low cost advantage:}

An institution can achieve the low cost advantage if the costs relating to value producing activities are less than those of competitors. So, to achieve low cost advantage the organization must monitor the factors of cost evolution.

\section{Differentiation advantage:}

Differentiation implies distinguishing yourself from rivals by offering something that they find hard to match. Differentiation gives a company two advantages: (Hill, et al., 2013, p.157)

- First, it can allow the company to charge a premium price for its good or service, should it chose to do so.

- Second, it can help the company to grow overall demand and capture market share from its rivals.

According to Abo Bakr, (2004, pp.114,115*) there are two main dimensions of competitive advatage;" Customer perceived value and differentiation".

\section{$>$ Customer perceived value:}

In order to achieving a competitive advantage customers must perceived that the value they obtain from dealing with an organization is higher than other competitors. So, an organization must exploit its diversified capabilities and resources to improve customers perceived value through many ways such as (price, quality comparing by price or economic degree, after-sales service, and so on).

\section{Differentiation:}

It means differentiate product whereas competitors find it difficult to imitate or even copy. In order to achieve differentiation there are four sources must be obtained: (Financial resources, material resources, human resources, and organizational capabilities).

\section{Hotel Products}

According, Kotler and Armstrong(2016, p.230), Product can be defined as anything that can be offered to a market for attention, acquisition, use, or consumption that might satisfy a want or need. Whether, it's services, events, persons, places, organizations, ideas, or a mixture of these. 
They also defined Services as "A form of product that consists of activities, benefits, or satisfactions offered for sale that are essentially intangible and don't result in the ownership of anything".

According to Ahmed(2016, p.46*) in hotel industry products are divided into two types; physical product, and services:

- Physical products: those are provided to customers in tangible and visible form, such as, food and beverage, supermarkets, and shops those are attached to the hotel.

- Services: are naturally intangible, such as, tours, the level of room service, and the level of doorman or bellman service.

Kotler and Armstrong(2014, pp.260and 2016, pp.242-244) indicated that service has four special characteristics represented in: intangibility, inseparability, Heterogeneity, and perishability.

- Service intangibility: means that services can't be seen, tasted, felt, heard, or smelled before they are bought.

- Service inseparability: refers to services' inability to be separated from their providers, and also it cannot be separated from its customers.

- Service Heterogeneity: means that the quality of services depends on who provides them as well as when, where, and how they are provided.

- Service perishability: means that services cann't be stored for later sale or use and are perishable.

According Abdel-Samee and Ahmed, (2016*) and Hill, et al.(2013) hotels can build a product competitive advantage through: (differentiation, efficiency, quality, innovation, customer responsiveness).

\section{Hotel Products Differentiation}

According Abdel-Samee and Ahmed, (2016, pp. 174-177*) the success and differentiation of tourism service depends on many factors as follows:

- The extent of service differentiation: it means the volume of the service's advantages; those do not exist in the competitors' service.

- The nature of service: whenever the service's offering is more ease and convenience, whenever it is the more useful and attractive to clientele. 
- The service providing style: customers usually care about the style of providing the service, beside their attention to the quality level and how much advantages and benefits those satisfy their different needs.

- The clarity of service: the providing service must be clear and well-known to the customers.

- The high of service level: the high service level increases the demand.

- The suitability of service prices: costumers usually search for the best service with suitable price.

According to Hill, et al., (2013, pp. 93-97)

- Hotel Products Efficiency: Company is efficient, when it has higher productivity, and lower costs, than its rivals.

- Hotel Products Quality: A product is said to have superior quality when customers perceive that its attributes provide them with higher utility than the attributes of products sold by rivals.

- Hotel Products Innovation: Innovation of hotel products and processes seems to be the most important building tool of competitive advantage, as innovations considered a process that drive competition.

- Customer Responsiveness: Achieving superior responsiveness to customers, means giving customers value for money, by giving them what they want, when they want it, and at a price they are willing to pay.

\section{Attracting Customer}

Because customers always search for satisfaction and say " if you satisfied me you will own me" Abdel-Hamed, (2014, p.13*), a successful marketer should work constantly to find out what the consumer wants, in order to be able to change production or presentation strategies and develop products to better fit consumers' wishes and satisfy their demands (Padgham,2005).

As the customer purchasing decisions are affected by various factors such as, (product price, design, packaging, knowledge about the product, quality, celebrity endorsement, and family relation ((Padgham,2005). So, marketing is the main way to attracting customers, by promised to satisfy their needs and desires. 
Hotel Marketing is defined as "the efforts that hotel establishments exert due to recognize and influence the internal and external tourist markets in order to increase the hotel traffic and occupancy rate" (Abdel-Samee and Ahmed, 2016, p.49*).

Consequently Hotels should:

1. Design their products/services to meet customer needs and wants;

2. Focus on those people most likely to buy their product rather than the entire mass market; and

3. Develop marketing efforts that fit into their overall business objectives. (Raju, 2009, p.3)

\section{Methodology}

- Population: The current study attempts to identify the influence of the hotel products' competitive advantage in customers attracting. The total number of five-star hotels and touristic resorts at Sharm El Sheikh City are (41) hotels and resorts as mentioned by Egyptian hotel guide the 33rd Edition (2012-2013). The population of this study was composed of all customers of five-star hotels at Sharm El Sheikh City.

- Sample size: The researcher determined (21) hotels with a percentage of closer to (50\%) from the total population which is (41) hotels and resorts at Sharm El Sheikh City. Only (11) five-star hotels of the determined (21) hotels accepted to help us in making the empirical study.

A total of (400) forms have been distributed randomly on the investigated sample in three different languages (Arabic, English, and Russian) to answer them according to their perceptions, only 324 forms were valid to analysis, which represent $81 \%$ of the sample size.

\section{- Data collection method:}

A self - administrated questionnaire form was developed in order to measure the impact of hotel products competitive advantage (presented in: product differentiation, product efficiency, product quality, and product innovation) as independent variable on Attracting Customers as dependent variable. The questionnaire form was distributed to customers of five- star hotels at Sharm El Sheikh, at a random way to obtain a systematic random sample of respondents; each respondent was informed of the study objective before been given a questionnaire form. 


\section{Data Analysis}

\section{Descriptive Statistics:}

The descriptive statistics is conducted in order to recognize the computed mean of each scale items and determine which items hotels are interested in more than others, from the customers' view

\section{Table.1: Descriptive Statistics of Hotel products Competitive}

Advantage

\begin{tabular}{|c||c||c||c||c||c|}
\hline Variables & $\begin{array}{c}\text { P. } \\
\text { Differentiation }\end{array}$ & $\begin{array}{c}\text { P. } \\
\text { Efficiency }\end{array}$ & $\begin{array}{c}\text { P. } \\
\text { Quality }\end{array}$ & $\begin{array}{c}\text { P. } \\
\text { Innovation }\end{array}$ & $\begin{array}{c}\text { Attracting } \\
\text { Customers }\end{array}$ \\
\hline Means & 4.14 & 4.22 & 4.35 & 4.11 & 4.30 \\
\hline
\end{tabular}

Table (1) shows that the computed mean for the hotel products competitive advantage are as following:

$>$ The computed mean of hotel products differentiation is 4.14 with a percentage of $(82.8 \%)$ which is a moderate percentage.

$>$ The computed mean of hotel products efficiency is 4.22 with a percentage of $(84.4 \%)$ which is a high percentage.

$>$ The computed mean of hotel products quality is 4.35 with a percentage of $(87 \%)$ which is a high percentage.

$>$ The computed mean of hotel products innovation is 4.11 with a percentage of $(82.2 \%)$ which is a moderate percentage.

$>$ The computed mean of attracting customers is 4.30 with a percentage of $(86 \%)$ which is a high percentage, and indicates that the customers are satisfied about the hotels products.

This results show that the hotel products quality is the most important factor in hotel products competitive advantage, but this doesn't deny the importance of other attributes as all scales can lead to each other.

\section{Testing Hypothesis:}

In order to test hypothesis the researcher used, Multiple Regression Model: in order to measure the significance extent of each independent variable (P. Differentiation, P. Efficiency, P. Quality, and P. Innovation) effect on attracting customers (dependent variable).

There is a significant effect of hotel products competitive advantage on attracting customers. Which is divided into four sub hypotheses as follows:

H1. There is a significant effect of hotel products differentiation on attracting customers. 
H.2. There is a significant effect of hotel products efficiency on attracting customers.

H3. There is a significant effect of hotel products quality on attracting customers.

H4. There is a significant effect of hotel products innovation on attracting customers.

Table (2): Testing the Tendency of Hotel products Competitive Advantage in Affecting Attracting customers

\begin{tabular}{|c|c|c|c|c|}
\hline $\begin{array}{c}\text { Hotel products } \\
\text { competitive } \\
\text { advantage }\end{array}$ & $\mathbf{R}$ & $\begin{array}{c}\mathbf{R} \\
\text { Square }\end{array}$ & $\begin{array}{c}\text { Adjusted R } \\
\text { Square }\end{array}$ & $\begin{array}{c}\text { Std. Error of } \\
\text { the Estimate }\end{array}$ \\
\cline { 2 - 5 } & $.849 \mathrm{a}$ & .720 & .716 & .37624 \\
\hline
\end{tabular}

a. Predictors: (Constant), Innovation, Efficiency, Differentiation, Quality

Table (2) illustrates that $\mathrm{R}$ which measure the correlation degree of the independent variables combined with the dependent variable is close to $85 \%$ which is an excellent degree. As well as R2 which shows that the hotel products competitive advantage factors or at least one of them contribute with $(72 \%)$ on attracting customers, and about $28 \%$ of changes in attracting customers are influenced by other variables. Which ensure the importance of creating product competitive advantage in hotels and its role in attracting customers.

Table (3): The influence of Hotel products competitive advantage on attracting customers

\begin{tabular}{|c|c|c|c|c|c|}
\hline Model & $\begin{array}{c}\text { Sum of } \\
\text { Squares }\end{array}$ & df & $\begin{array}{c}\text { Mean } \\
\text { Square }\end{array}$ & F & Sig. \\
\hline Regression & 114.674 & 4 & 28.669 & 202.526 & $.000 \mathrm{~b}$ \\
\hline Residual & 44.590 & 315 & .142 & & \\
\hline Total & 159.264 & 319 & & & \\
\hline
\end{tabular}

a. Dependent Variable: Attracting

b. Predictors: (Constant), Innovation, Efficiency, Differentiation, Quality.

Sig: < 0.05

Data presented in table (3) illustrates the influence of hotel products competitive advantage on attracting customers. According to the degree of significance which is less than 0.05 , the researcher concluded that there is a 
مجلة كلية السياحة والفنادق - عدد r - ديسمبر r.1V $\quad$ - r.

significant relationship between hotel products competitive advantage and attracting customers.

\section{Table (4)}

The Relationship between hotel products competitive advantage and attracting customers

\begin{tabular}{|c|c|c|c|c|c|}
\hline \multirow{2}{*}{ Model } & \multicolumn{2}{|c|}{$\begin{array}{c}\text { Unstandardized } \\
\text { Coefficients }\end{array}$} & $\begin{array}{c}\text { Standardized } \\
\text { Coefficients }\end{array}$ & \multirow{2}{*}{$\mathbf{t}$} & \multirow{2}{*}{ Sig. } \\
\cline { 2 - 5 } & B & Std. Error & Beta & & \\
\hline (Constant) & $-.916-$ & .193 & & $-4.737-$ & .000 \\
\hline P. Differentiation & .261 & .060 & .213 & 4.331 & .000 \\
\hline P. Efficiency & $-.184-$ & .054 & $-.184-$ & $-3.386-$ & .001 \\
\hline P. Quality & 1.070 & .092 & .769 & 11.647 & .000 \\
\hline P. Innovation & .064 & .046 & .067 & 1.400 & .163 \\
\hline
\end{tabular}

a. Dependent Variable: Attracting

In table (4) the Significance was used to determine whether the attributes tested has a significant or insignificant impact on attracting customers. From the results shown in table the researcher conclude that:

- Hotel products Differentiation and Hotel products Quality: has a positive relation and significant impact on attracting customers, as its sig $=.000$, is $(\mathrm{a} \leq 0.05)$. Therefore hypothesis (H1 and $\mathrm{H} 3)$ are accepted.

- Hotel products Efficiency: has a negative relation and significant impact on attracting customers, as its sig $=.001$, is (a $\leq 0.05)$. Therefore hypothesis $(\mathrm{H} 2)$ is accepted.

- Hotel products Innovation: has a positive relation but doesn't have a significant impact on attracting customers, as its sig $=$ .163 , is $(\mathrm{a} \geq 0.05)$. Therefore hypothesis (H4) is refused.

So the hypothesis "There is a significant effect of hotel products competitive advantage and attracting customers", is accepted in the terms of hotel products differentiation, hotel products efficiency, and hotel products quality. And is refused in the term of hotel products innovation.

From the previous analysis we can notice that the quality and differentiation is the major variables in affecting attracting customers, followed by efficiency. 


\section{Conclusion}

This study aims at measuring the impact of competitive advantage of hotel products (presented in; hotel products differentiation, hotel products efficiency, hotel products quality and hotel products innovation) on attracting customers.

In conclusion and after reviewing related literature, designing data collection method, collecting data from sample units and analyzing data to test the research hypothesis. It was found that:

Hotel products competitive advantage has significant effect on attracting customers concerning to hotel products differentiation, hotel products efficiency and hotel products quality, while concerning to hotel products innovation it doesn't have any significant effect on attracting customers. As well as the descriptive analysis illustrate the importance of all hotel products competitive advantage factors, however it determined that hotel products competitive advantage quality is the major factor.

These results indicate that the value of hotels is based on its products because it is the main reason of attracting customers.

\section{Recommendations}

Upon the results obtained, the following suggestions are:

The necessity of paying attention of hotel product distinct: as the main reason of attracting costumers is product. So, the hotel products must be distinctive over other customer, this distinct can be achieve through obtaining a product competitive advantage, by:

- Caring about the hotel product differentiation,

- Caring about the hotel product quality,

- Caring about the hotel product efficiency, and

- Caring about the hotel product innovation

The necessity of paying attention of technology: due to the constantly evolution the hotels must interest in technology, to keep up with customers.

Hotels need to give more interest to study customers' needs.

$>$ The intensity of maintaining a continuous competitive advantage of hotel products

The Tourism Ministry must give more interest to promoting the tourism destination and highlight the tourism strengths according to the target market. 
1Research Master Thesis Faculty of Tourism and Hotels- Mansoura University

2 Lecturer of Hotel management- Faculty of Tourism and Hotels - Mansoura University

3 Prof. of Business Administration - Faculty of Commerce - Mansoura University

$$
\begin{aligned}
& \text { ؛ أستاذ النسويق بكلية التجارة جامعة المنصورة }
\end{aligned}
$$

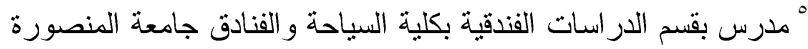

$$
\begin{aligned}
& \text { باحثة بالدر اسات العليا كلية السياحة و الفنادق جامعة المنصورة }
\end{aligned}
$$

* In Arabic

* In Arabic

* In Arabic

* In Arabic

* In Arabic

* In Arabic

${ }^{*}$ In Arabic

* In Arabic

\section{References}

\section{English References:}

\section{Books:}

1. Enz, C.A., (2010), Hospitality Strategic Management: Concepts and Cases, New Jersey, John Wiley and Sons, Inc.,.

2. Hill, C. W.L., Jones, G.R. and Schilling, M.A., (2013), Strategic Management: Theory, $\mathbf{1 1}^{\text {th }}$ ed., (Cengage Learning).

3. Porter, M.E. (1998a), Competitive Strategy: Techniques for Analyzing Industries and Competitors: With a New Introduction, (New York Free Press).

4. Porter, M.E. (1998 b), Competitive Advantage: Creating and Sustaining Superior Performance: With a New Introduction, (New York Free Press).

5. Kotler, P. and Armstrong, G., (2014), Principles of Marketing, $\mathbf{1 5}^{\text {th }}$ ed., (Pearson Education,).

6. Kotler, P. and Armstrong, G. (2016), Marketing: An Introduction, 13th edition., (Pearson Education,).

7. Raju, G. P., (2009), Tourism Marketing and Management, (Manglam Publications). 


\section{Periodicals:}

1. Frehse, J., (2008). Innovative Product Development in Hotel Operations, Journal of Quality Assurance in Hospitality and Tourism, 6:3-4, pp. 129-146.

2. Kim, B.Y. and Oh, H.,(2004). How do hotel firms obtain a competitive advantage?, International Journal of Contemporary Hospitality Management, Vol. 16 Iss 1, pp. $65-71$.

3. Mathews, V.E., (2000). Competition in the international hotel industry, International Journal of Contemporary Hospitality Management, Vol. 12 Iss (2), pp.114-118.

4. Siqueira, A., C. and Cosh, A., D., (2008). Effects of Product Innovation and Organisational Capabilities on Competitive advantage: Evidence from UK Small and Medium Manufacturing Enterprises, International Journal of Innovation Management, Vol. 12, No. 2, pp. 113-137.

\section{Reports:}

Padgham, J., (2005). Strategies to Attract and Keep Customers, Board of Regents of the Wisconsin University, pp. 1,2.

\section{Arabic References:}

1. متولى، أحمد حسن ، إدارة الفنادق و المنتجعات السياحية، (دار المنار

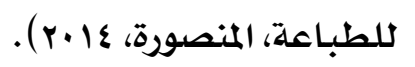

r. البكري، ثامر ، إستراتيجيات التسويق ، (دار اليازوري للنشر، الأردن ، · ·ـr).

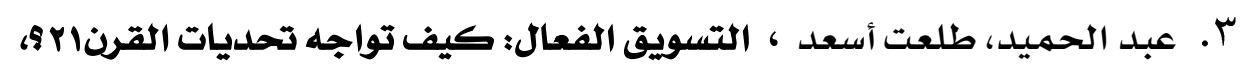

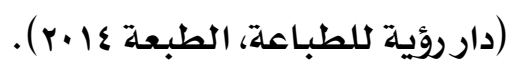

ع. عبد السميع، صبرى - أحمد، محمد عبد العزيز سيد ، التسويق الفندقى،

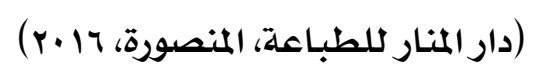

0. أبو بكر، مصطفى محمود ، الموارد البشرية مدخل لتحقيق الميزة التنافسية،

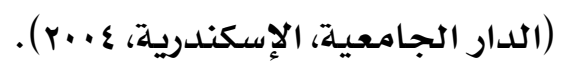

